\title{
Commercialization of Medicinal Plants in Java Island, Indonesia
}

\author{
Ignatius Adi Nugroho $^{1 *}$, Dodik Ridho Nurrochmat ${ }^{2}$, Hardjanto ${ }^{2}$ \\ 'Graduate School of Bogor Agricultural University, Dramaga Campus, Bogor, Indonesia 16680 \\ ${ }^{2}$ Departement of Forest Management, Faculty of Forestry, Bogor Agricultural University, \\ Academic Ring Road, Dramaga, Campus, Bogor Indonesia, 16680
}

Received April 4, 2016/ Accepted June 21, 2016

\begin{abstract}
The benefit and transaction cost flow which people earn economically and socially from wild medicinal plant harvesting are addressed in this study. The objectives of this study are three aspects: defining how many users are involved in utilization of medicinal plant raw materials (MPRM), how users describing their perception and motivation and describing benefit and transaction cost which influence users to harvest the plants. Results showed that utilization of medicinal plants in Java is still widely used as commercial products then medical services. There are 41 stakeholders who involved in this study and the highest motivation and perception in production and industrial clusters are economic interest. But stakeholder's perception and motivation in traditional healthcare cluster is social interest. The different motivation and perception in both clusters causing stakeholder who are work in traditional healthcare lack of market information, but they are important if the government will improve the traditional medicine. Recommendation of this study is that medicinal plants need further research and product development which can help to expand the medicinal plant culture area in the natural forest. By this reason, government should develop good political will to increase the medicinal plant resources for public healthcare.
\end{abstract}

Keywords:benefit, transaction cost, medicinal plant, stakeholder, commerce

*Correspondence author, email: toekang_jamoe@yahoo.co.id,phonelfax: +62-21-77829938

\section{Introduction}

Medicinal plants are one of among non timber forest products (NTFPs) which people using directly its raw materials to produce many products which widely found in the local, national or international where village communities collecting raw materials from wild harvest such as from protection, production, and national parks forest in Java Island (Zuhud \& Hikmat 2009). Practically, the community develop a group namely pendarung who have skill to harvest medicinal plants from the forest. Each group usually consists of three or four persons with specialization in collecting, climbing tree, or selling products. They go to the forest in the fruiting season of medicinal plants. After harvesting, people sell their medicinal plants directly to a buyer and will earn money as benefit exchanged from the medicinal plants' raw material (Mbuvi et al. 2015).

The first buyers, sometimes called pengepul, sell again that raw material to other buyers and all process creates the supply chain of the raw materials from pendarung to the end users. It is also involve the benefit and transaction cost when exchange of medicinal plant raw materials happened. The process of medicinal plants commerce is continuing and being stopped when the end users consume those medicinal plant products. Certain buyers maximize their benefit and minimize transaction cost, so that the price of raw materials more expensive to the next users and by that modus they earn maximum beneficiaries (Stenley et al. 2012). In this condition, natural forest plays important role as the main supplier of MPRM and people play as users of those resources (FAO 1995).

Our study focused on benefit and transaction cost flow which people earn economic and social benefit from medicinal plants harvesting and trading. These also involve user's perception and motivation to the natural forest when they use interest to MPRM. This study covers three aspects, firstly to define how many users who are involved to the medicinal plant raw materials utilization. Secondly, to identify how the users describe their perception and motivation to the raw material of medicinal plants and thirdly, to describe benefit and transaction cost which influence the users to harvesting the medicinal plants.

\section{Methods}

This study was conducted in three areas namely Meru Betiri National Park (MBNP) in East Java, Yogyakarta Province, and Sukoharjo District in Central Java. The location was chosen as it is where users of medicinal plants core activities are located. The utilization of these medicinal plants is in the production, traditional healthcare and industries. In this study, location of study divided into three 
clusters. To provide clearer information process of study is illustrated in Figure 1. This study was carried out in November 2014 to August 2015. The strategy to capture data, were purposive approach and after that, continued the snowball technique to start interview to the respondent. This technique also helps us to define the key informant of the user who is participating in medicinal plant activities in each cluster (Marsh \& Stoker 2011). The smallest unit of key informant is a stakeholder who has sufficient knowledge on medicinal plants (species recognition, harvesting time, what part to be collected, purposes, how to process etc).

Production cluster Meru Betiri National Park (MBNP) has been known as the biggest source of medicinal plants resources in Indonesia. It has 291 species of medicinal plants which people actively use as raw materials from MBNP (Zuhud \& Hikmat 2009). Users of medicinal plants in East Java controlled production and distribution chain of raw materials which one of those was flowing out from MBNP. The raw materials are originally from cultivated farm and natural harvesting from forest (Harnock 1992; Hamilton 2004; Brinckmann 2015). In this study, the medicinal plant raw materials from East Java are called as production cluster because all activities of medicinal plants are concentrated on raw material production. Data are captured from two villages in MBNP i.e. Andongrejo and Curahnongko. Both villages have a community who collects medicinal plant from the natural forest. Members of that community sell raw materials of medicinal plant to buyer which lived in both villages, and after that, the buyers sell it to sub district traditional market.

Industry cluster After East Java, traffic of medicinal plants flow to Central Java and Yogyakarta. The raw materials of medicinal plant are proceeding to other products in Sukoharjo District. Users applied modern manufacture technology to extract raw materials and develop into herbal product and sell all herbal products in traditional herbal market namely "Pasar Nguter". It is the biggest traditional herbal market in Indonesia which services all buyers of herbal products. They come from several provinces in Indonesia, such as Jambi, North Sumatera, East Nusa Tenggara, South Sulawesi etc. Then, they resell the herbal products, generally in beverage form, to those provinces. Activities in herbal industries have increased income of local

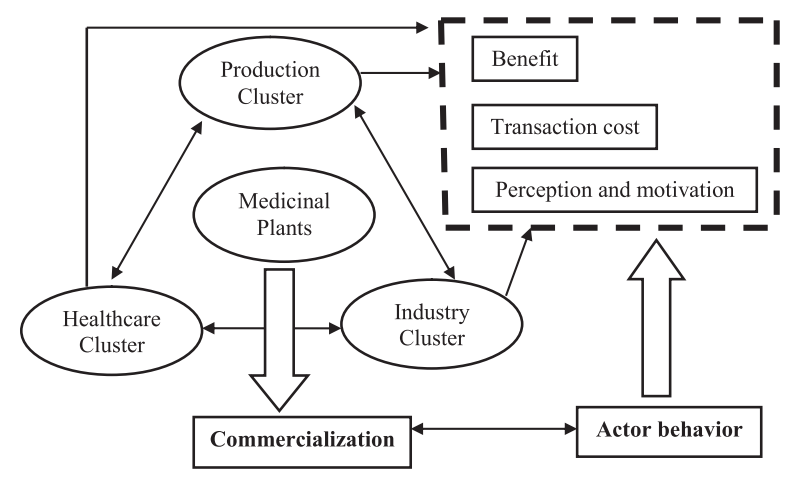

Figure 1 The process of medicinal plants commercialization. community, hence the industries an economic driver in Sukoharjo District by providing employment. Furthermore, Indonesia central government developed herbal industries in Sukoharjo District, then stated Sukoharjo District as "Kabupaten Jamu" in April 2015. All programs related are supervised by Coordinator Ministry of Economic of Republic Indonesia. In the study, herbal industries ware defined as industry cluster. From this cluster, it is hoped that distribution of raw material could be described. The data captured in Nguter village where herbal manufactures are developed. Dominantly, they are small-medium scale manufactured (Torri 2012).

Healthcare cluster The other study area is Yogyakarta Province. In this location, it was found that people are relatively familiar with traditional culture. One of common the cultures among the people are traditional healthcare. Originally, this culture is use and practiced in kraton (a javanese kingdom) neighborhood. Herbal products have been used to beauty care of kraton's ladies and maintain their health performance. It is important because a king always demand them to perform traditional dancing in front of him every day. Todays, those traditional cultures disperse to community in Yogyakarta (Torri 2012; Beers 2013). People may use herbal product to care their health. Based on this reason, this location is defined as healthcare cluster. Data were captured in Yogyakarta capitol where healthcare are distributed at different location namely primary health facility services (clinic), secondary health facility services (hospital), herbal grocery stores, traditional community, and NGO. Many traditional healthcares in this cluster were serviced by traditional healers.

Commercialization Webster translates commercialization as process to use something as an opportunity to earn money. Moreover, medicinal plants as raw material are turned into marketable goods with monetary/exchange value. Mehrabi et al. (2013) defined commercialization as a process of creating product that is suitable for a specific market with an acceptable price which can satisfy market needs. Furthermore, Kockelman (2006) defined commodity as material and non-material product. Commercialization in this study means a process how raw materials of medicinal plant from production cluster exchange into other raw materials which people used them as beverages or traditional healthcare. Usually, the raw materials of medicinal plant in production cluster are harvested wildly from MBNP. These wet raw materials should be dried before selling to other users and this process determines quality of raw material and its price. Those conditions also lead instability price for users when rainy seasons come. Rotten and fungus infected raw materials occurs especially in the rainy seasons which cause the supply of the raw materials quality decreased. As consequent, user always accept lower price (Zuhud et al. 2009; Bauri et al. 2015).

In industry cluster, handling raw material of medicinal plants is better than in production cluster. Manufactures have specification on processing and handling before raw materials accepted from production cluster. Those processes should pass quality control section and testing of all materials that are free from fungus, rotten and dirty materials 
(Singh 2015). After that, the raw materials of medicinal plant are ready for secondary processing to other products. Almost all process use modern industrial machinery and diminish people activities. It means that industrial technology i.e. machinery is a vital aspect in this cluster. Most of products in this cluster are beverage products that all items are sold to inter islands within Indonesia. Even some industries sell those products to international countries using advertisement and media to promote their products (Kitzberger 2012). It encourages positive image for herbal products and increase the value (Bhattacharjee 2012). These are the source of income for the manufacturer. They use the income to buy investment products i.e. family insurance, employee or develop production technology. Briefly, in this cluster, raw materials of medicinal plant disperse and exchange in many form not only herbals or beverage products but also create an opportunity for user to invest on insurance products as other side benefit from those activities.

In healthcare cluster, traditional healers use dried raw materials of medicinal plant. They obtain the raw materials from traditional market and sometimes some suppliers send products to them. Healers, suppliers and traders of raw material create a good relationship among them and by that, intencity of raw material moves fluently in traditional healthcare arena. Actually, the relation has taken place for a long time. Many temples in Yogyakarta province describe reliefs how ancient traditional communities used raw materials of medicinal plant. The relief figure out relations between healers and their patients (Beers 2013). Until now, those relations continue and people always use healers as important parts of their daily lives. In some cases, the relations also develop in modern perspectives. Government supports by developing policies that raw material of medicinal plants could be researched and developed. By such policies, many medicinal plants products support quality of public health services. Although there are still products from traditional healthcare that have not reach a satisfying standard, but the policies have provided an opportunity for scientists to develop product furthermore. Today, Indonesian researchers have reached eight products categorized as clinical tested, but those are still not sufficient to fulfill traditional public health needs (Dewoto 2007). Many new and complex diseases of people have been formed and those also need some handling soon. It caused traditional healthcare still needs continuous researchs and financial support to produce the best quality of traditional medicinal plant products (Taylor 2002).

Actors behavior The study was focused on actors behavior as drivers for commercialization of medicinal plants processing (Hermans \& Thiessen 2008; Reed et al. 2009; Nurrochmat et al. 2015). It is underlined that human behavior need to discuss in 3 clusters because those have correlations with commercialization of raw materials (Taylor 2002). It as also important that human behavior and commercialization will become political ecology problems in future, since those activities could be decreased medicinal plants resources if people continue their demand without control on raw materials (Bryan \& Bailey 1997). In this study, human socioeconomic approaches were used to analyze various user activities i.e. benefit, transaction, perception and motivation.
Benefit is defined as what people earn from their economic activities. Benefit cost ratio approaches were applied to describe distribution of benefit among actors who get involved in medicinal plants utilization. Benefit cost ratio is ratio between revenue and cost (Mamat et al. 2010).

\section{$\mathrm{B} / \mathrm{C}$ Ratio $=\frac{\text { Benefit }}{\text { Cost }}$}

We used this formula in undiscounted BCR condition with criterion below:

People will involve in a project if $\mathrm{BCR}$ value $>1$. Otherwise, if $\mathrm{BCR}$ value $=1$, people perhaps still involve in the project because they hope that benefit will be earned in future. Finally, if BCR value $<1$, people completely denied the project because there will be no benefit at all.

1 Transaction cost

Transaction cost means all costs that people spend to get information about medicinal plants, including tax pricing, products development, and other cost related to product security (Tita et al. 2011). In this research, transaction cost methodology was used to know fixed cost and variable cost (Collins \& Fabozzi 1991; Yustika 2006).
Transaction cost
Fixed Costs
Variables Costs
$=$ Fixed Costs + Variable Costs
Execution Cost
$=$ Commission + Transfer Fees + Taxes
Opportunity Costs = Desired Returns-Actual Returns -
Execution Costs - Fixed Costs

In this section, transaction cost is divided into 2 ways: $a d$ valorem and lump sum. Ad valorem transaction is defined as trade cost that all costs should be paid by trader or consumer to goods or service in commerce transaction. This value transaction draws government policy in commercial arena, i.e. tax, retribution, rent etc. (Crozet \& Soubeyran 2004; Wang 2010). People pay goods or service based on their volume per transaction. Whereas, lump sum transaction relates to costs that should be paid by people to control their property rights as high risk assets (Zhang 2001; Barron \& Karpoff 2002; Liu 2004). It is characterized by time transaction and often people pay their transaction permanently. So, by such definition, transaction cost is function of lump sum cost and ad valorem cost. Both costs also describe illegal and legal transaction in commerce of medicinal plant raw materials.

\section{Perception and Motivation}

Perception and motivation are variables which describe human interests (Febriani 2012). In some cases, those variables also become drivers for people to reach their purposes, i.e. harvesting medicinal plants from natural forest or from cultivation area. Webster dictionary defines perception as the way people think about or understand someone or something. Perception is also an important cognitive function at subconscious layers that determines personality (Wang 2007). Moreover, motivation is defined as act or process of giving someone a reason for doing something (Guay et al. 2010; Lai 2011). Terminology of "think" and "a reason" relatively have close correlation with interest. Interest is defined as individuals, people or group who defend their desire to 
others. From that process, people build some strategies and concepts to achieve actual needs in real condition. Interest is also restricted by real constraints such as rules, social structures, beliefs, religion, traditions and other motives which 'live' in social or material dimension (Shapiro 2006). By those definitions, it is assumed that people have various interest to utilize medicinal plant. Each interest represented their think and reason to get beneficiaries from those activities. It is also involved transaction cost when users earn some benefits. Data on interests were obtained by interview to respondents. Finally, the data were categorized into rows of user's perception and motivation.

\section{Results and Discussion}

Users of medicinal plants The result of this study showed that there were ten users in production cluster, nineteen users in healthcare clusters and twelve users in industry cluster who utilized medicinal plants. All users should be understood as stakeholders using raw material of medicinal plants in those clusters actively. Those activities flow from natural forest to end users in households sectors. They are most in healthcare cluster because this cluster captures basic service for households in traditional healthcare. They have important role as consumers of medicinal plants by created market of medicinal plants. Table 1 shows users of medicinal plants in three clusters and their perception and motivation to those products.

Benefit and transaction cost Benefit and transaction cost are 2 variables which have correlated with commercialization of medicinal plant products by commerce activities. Table 2 shows distribution values of benefit cost and transaction cost variables. Benefit cost has been pointed by benefit cost ratio (BCR); while transaction costs have represented by other cost which users should pay more when they need to exchange products. This term also describes legal and illegal transaction among users to earn income.

Perception and motivation Based on Table1, there are 41 stakeholders using medicinal plant products (Table 1). They are dispersing from production, industrial and traditional healthcare clusters which each stakeholder has an interest to use medicinal plants raw material. It means interest also reflects user's perception and motivation. Although their perception and motivation are differ, continually collection of medicinal plants from wild will affect their population in natural forest lead to in-sustainability of those species. By this reason, in Table 3, it is informed that stakeholder's perception and motivation have closely correlated with economic, social, sustainability and heritage values. Table 3 was derived from Table 1 by formulating into usage values and percentage of perception and motivation.

Based in the data in Table 3 indicated that economic value became the highest choice of stakeholders in production cluster. It has been shown by their perception and motivation values about 50 and $60 \%$, respectively. The economic value is the biggest interest among users in that cluster and also has the same choice in industrial cluster. The production and industry clusters have been connected to economic interest in medicinal plants activity, and by that argument, actually medicinal plants activity are part of medicinal plant commerce in Indonesia. Those specific connection influencing higher demand of medicinal plant. The MPRM continuously extracted from forest to fulfill the demand and it causing the numbers of raw materials also decreased in production cluster (Bukuluki et al. 2014). The key informant also argued that raw materials of medicine plant were more difficult to harvest in village periphery. Gatherers should go farther into deep forest and it means that they should spend more cost and time to get the raw materials. In this study, most harvesters never count their cost to reach raw materials even those are difficult, because their interest is only to earn income for their family. Generally harvesters never count their cost strictly because medicinal plants are traditional

Table 1 The Users of Medicinal Plants Products and Their Perception and Motivation

\begin{tabular}{|c|c|c|c|}
\hline & Stakeholders & Perceptions & Motivations \\
\hline \multirow{13}{*}{$\begin{array}{l}\text { Production } \\
\text { Cluster }\end{array}$} & MBNP management officer & Sustainability of forest & Law administration \\
\hline & & natural resources & \\
\hline & Plantation and Forestry officer of & Sustainability of forest & Law administration \\
\hline & Jember District & natural utilization & \\
\hline & Farmers Group & Added income & Income \\
\hline & Medicinal plants harvester & Added income & Income \\
\hline & Medicinal plants buyer & $\begin{array}{l}\text { Added income if main } \\
\text { income decreased }\end{array}$ & Income \\
\hline & Owner of households industry of & Biodiversity and & Income and economic \\
\hline & medicinal plants & heritage value & opportunity \\
\hline & Logger & Income and prosperity & Follower \\
\hline & Bandealit plantation officer & $\begin{array}{l}\text { Low attention to forest } \\
\text { natural resources }\end{array}$ & $\begin{array}{l}\text { Economic beneficiaries } \\
\text { from plantation }\end{array}$ \\
\hline & Lead of NGO of KAIL & $\begin{array}{l}\text { Sustainability of forest } \\
\text { resources }\end{array}$ & $\begin{array}{l}\text { Conservation and } \\
\text { prosperity for others }\end{array}$ \\
\hline & Logs buyer & Logs commerce & Economic beneficiaries \\
\hline Healthcare & Spiritualist of java's religion & Herbal medicine as & Help other people \\
\hline Cluster & & cultural heritage & \\
\hline
\end{tabular}


Table 1 Continued

\begin{tabular}{|c|c|c|c|}
\hline & Stakeholders & Perceptions & Motivations \\
\hline & Doctor from Dr Sardjito hospital & $\begin{array}{l}\text { Herbal medicine as } \\
\text { complementary } \\
\text { healthcare }\end{array}$ & Herbal scientific policy \\
\hline & Doctor from Panti Rapih hospital & $\begin{array}{l}\text { Herbal medicine as } \\
\text { complementary } \\
\text { healthcare }\end{array}$ & $\begin{array}{l}\text { Herbal base to } \\
\text { healthcare services }\end{array}$ \\
\hline & $\begin{array}{l}\text { Founder of Lakutama } \\
\text { foundation }\end{array}$ & $\begin{array}{l}\text { Herbal medicine as } \\
\text { cultural heritage }\end{array}$ & Help other people \\
\hline & Owner of herbal grocery store & Income & $\begin{array}{l}\text { Preservation of family } \\
\text { heritage }\end{array}$ \\
\hline & $\begin{array}{l}\text { President director of PTPJT Dr. } \\
\text { Sardjito }\end{array}$ & $\begin{array}{l}\text { Economic opportunity } \\
\text { and public healthcare } \\
\text { services }\end{array}$ & $\begin{array}{l}\text { Preservation of research } \\
\text { knowledge heritage } \\
\text { from doctor Sardjito }\end{array}$ \\
\hline & $\begin{array}{l}\text { Head of herbal medical center of } \\
\text { Gadjah Mada University }\end{array}$ & $\begin{array}{l}\text { Opportunity to develop } \\
\text { new medicine }\end{array}$ & $\begin{array}{l}\text { Research and } \\
\text { development of herbal } \\
\text { medicine }\end{array}$ \\
\hline & $\begin{array}{l}\text { Head of herbal entrepreneur } \\
\text { associ ation Yogyakarta }\end{array}$ & Economic opportunity & $\begin{array}{l}\text { Utilization of ancestors } \\
\text { heritage }\end{array}$ \\
\hline & $\begin{array}{l}\text { Center of traditional therapy } \\
\text { Yogyakarta }\end{array}$ & $\begin{array}{l}\text { Healthcare services to } \\
\text { community }\end{array}$ & $\begin{array}{l}\text { Show window of } \\
\text { traditional herbal } \\
\text { medicine }\end{array}$ \\
\hline & $\begin{array}{l}\text { Board of drugs and foods officer } \\
\text { of Yogyakarta Branch office }\end{array}$ & $\begin{array}{l}\text { Protection to } \\
\text { community interest }\end{array}$ & $\begin{array}{l}\text { Guarantee to non- } \\
\text { chemical material in } \\
\text { herbal medicine }\end{array}$ \\
\hline & Traditional healer & Cultural heritage & $\begin{array}{l}\text { Application technology } \\
\text { to herbal healthcare } \\
\text { services }\end{array}$ \\
\hline & Herbal consumer & $\begin{array}{l}\text { Herbal benefit to care } \\
\text { family health }\end{array}$ & Cheap and safety \\
\hline & Patient of traditional healer & Healthcare alternative & Cheap and safety \\
\hline & Gondomanan policlinic officer & $\begin{array}{l}\text { First complementary } \\
\text { healthcare }\end{array}$ & $\begin{array}{l}\text { One of implementation } \\
\text { programs to public } \\
\text { healthcare }\end{array}$ \\
\hline & $\begin{array}{l}\text { Officer of Indonesia doctors } \\
\text { association Yogyakarta }\end{array}$ & $\begin{array}{l}\text { No evident base to } \\
\text { public healthcare }\end{array}$ & $\begin{array}{l}\text { Advocate the doctor } \\
\text { profession }\end{array}$ \\
\hline & $\begin{array}{l}\text { Patient of Spiritualist of java's } \\
\text { religion }\end{array}$ & $\begin{array}{l}\text { Wisdom word from } \\
\text { elder }\end{array}$ & Problem solver \\
\hline & $\begin{array}{l}\text { Officer of Bethesda community } \\
\text { development }\end{array}$ & $\begin{array}{l}\text { First healthcare to } \\
\text { village community }\end{array}$ & Hospital without wall \\
\hline & Healthcare officer of Yogyakarta & $\begin{array}{l}\text { Herbal healthcare } \\
\text { endorsement }\end{array}$ & $\begin{array}{l}\text { Administratively } \\
\text { implementation }\end{array}$ \\
\hline & $\begin{array}{l}\text { Priest from clinic of traditional } \\
\text { medic }\end{array}$ & $\begin{array}{l}\text { Healthcare is public } \\
\text { owner }\end{array}$ & $\begin{array}{l}\text { Socially services of } \\
\text { church }\end{array}$ \\
\hline \multirow[t]{4}{*}{$\begin{array}{l}\text { Industry } \\
\text { Cluster }\end{array}$} & $\begin{array}{l}\text { Entrepreneur of small scale of } \\
\text { herbal industry }\end{array}$ & Trade and income & $\begin{array}{l}\text { Continue the parent } \\
\text { business }\end{array}$ \\
\hline & $\begin{array}{l}\text { Owner of modern of herbal } \\
\text { grocery store }\end{array}$ & $\begin{array}{l}\text { Opportunity of herbal } \\
\text { market to expatriate } \\
\text { and young group }\end{array}$ & $\begin{array}{l}\text { Cultural heritage for } \\
\text { young group }\end{array}$ \\
\hline & Officer of Kompas newspaper & $\begin{array}{l}\text { Herbal industry is the } \\
\text { labor intensive and } \\
\text { driver for local } \\
\text { economy }\end{array}$ & $\begin{array}{l}\text { Encourage the new } \\
\text { small scale industry } \\
\text { development }\end{array}$ \\
\hline & $\begin{array}{l}\text { Officer of Center of bio- } \\
\text { pharmacy studies of Bogor } \\
\text { Agricultural University }\end{array}$ & $\begin{array}{l}\text { Standardized and } \\
\text { safety of herbal } \\
\text { products }\end{array}$ & $\begin{array}{l}\text { Result of herbal } \\
\text { prototype based on } \\
\text { research }\end{array}$ \\
\hline
\end{tabular}


Table1 Continued

\begin{tabular}{|c|c|c|}
\hline Stakeholders & Perceptions & Motivations \\
\hline $\begin{array}{l}\text { Head of Indonesia herbal } \\
\text { cooperation }\end{array}$ & $\begin{array}{l}\text { Information center and } \\
\text { marketing product of } \\
\text { herbals }\end{array}$ & $\begin{array}{l}\text { Help herbal industry as } \\
\text { the worship bridge }\end{array}$ \\
\hline $\begin{array}{l}\text { Her bal entrepreneur association } \\
\text { of Central Java Province }\end{array}$ & $\begin{array}{l}\text { Communication center } \\
\text { between government, } \\
\text { entrepreneur and } \\
\text { academic community } \\
\text { to develop good policy } \\
\text { for herbal }\end{array}$ & $\begin{array}{l}\text { Herbal industry } \\
\text { develops in own country }\end{array}$ \\
\hline Apothecary I & $\begin{array}{l}\text { Well known that herbal } \\
\text { has better beneficiary }\end{array}$ & $\begin{array}{l}\text { Field work and leisure } \\
\text { time }\end{array}$ \\
\hline Apothecary II & $\begin{array}{l}\text { Many small scale } \\
\text { herbal industry have } \\
\text { not licensed }\end{array}$ & $\begin{array}{l}\text { Field work and leisure } \\
\text { time }\end{array}$ \\
\hline $\begin{array}{l}\text { Board of drugs and foods officer } \\
\text { of Central Java Province }\end{array}$ & $\begin{array}{l}\text { Forest as the food and } \\
\text { medicinal plants } \\
\text { resources }\end{array}$ & $\begin{array}{l}\text { Drugs and foods safety } \\
\text { to consume the public }\end{array}$ \\
\hline $\begin{array}{l}\text { Entrepreneur of middle scale of } \\
\text { herbal industry }\end{array}$ & New field work & $\begin{array}{l}\text { Opportunity in herbal } \\
\text { industry }\end{array}$ \\
\hline $\begin{array}{l}\text { Entrepreneur of big scale of } \\
\text { herbal industry }\end{array}$ & $\begin{array}{l}\text { Open information and } \\
\text { innovation }\end{array}$ & $\begin{array}{l}\text { Proudly to work in } \\
\text { herbal in dustry }\end{array}$ \\
\hline $\begin{array}{l}\text { Commerce and industry officer } \\
\text { Sukoharjo District }\end{array}$ & $\begin{array}{l}\text { Herbal households } \\
\text { empowerment }\end{array}$ & $\begin{array}{l}\text { Government } \\
\text { administration }\end{array}$ \\
\hline
\end{tabular}

Table 2 Benefit and transaction cost distribution in three clusters

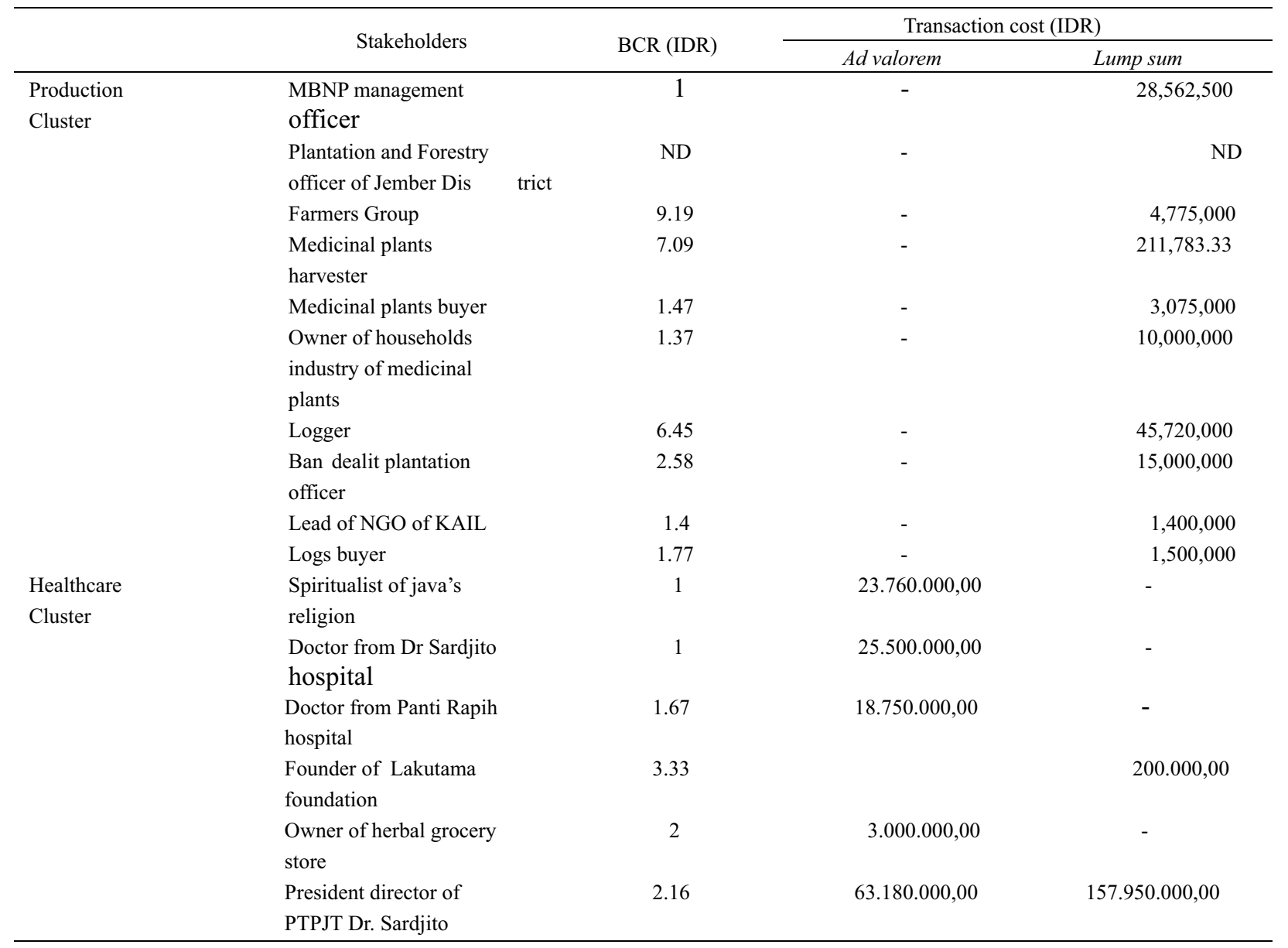


Table 2 Continued

\begin{tabular}{|c|c|c|c|c|}
\hline & \multirow{2}{*}{ Stakeholders } & \multirow{2}{*}{$\mathrm{BCR}$ (IDR) } & \multicolumn{2}{|c|}{ Transaction cost (IDR) } \\
\hline & & & Ad valorem & Lump sum \\
\hline & $\begin{array}{l}\text { Head of herbal medical } \\
\text { center of Gadjah Mada } \\
\text { university }\end{array}$ & 1 & - & - \\
\hline & $\begin{array}{l}\text { Head of herbal entrepreneur } \\
\text { association Yogyakarta }\end{array}$ & 1.36 & $2.700 .000,00$ & - \\
\hline & $\begin{array}{l}\text { Center of traditional } \\
\text { therapy Yogyakarta }\end{array}$ & 1 & $100.000 .000,00$ & - \\
\hline & $\begin{array}{l}\text { Board of drugs and foods } \\
\text { officer of Yogyakarta } \\
\text { Branch office }\end{array}$ & 1 & $2.800 .000,00$ & - \\
\hline & Traditional healer & 1.11 & $179.200 .000,00$ & - \\
\hline & Herbal consumer & 1 & $960.000,00$ & - \\
\hline & Patient of traditional healer & 16.67 & & - \\
\hline & $\begin{array}{l}\text { Gondomanan policlinic } \\
\text { officer }\end{array}$ & 1 & $6.560 .000,00$ & - \\
\hline & $\begin{array}{l}\text { Officer of Indonesia } \\
\text { doctors association }\end{array}$ & 1 & - & $95.000 .000,00$ \\
\hline & Yogyakarta & & & \\
\hline & $\begin{array}{l}\text { Patient of Spiritualist of } \\
\text { java's religion }\end{array}$ & 1 & - & - \\
\hline & $\begin{array}{l}\text { Officer of Bethesda } \\
\text { community development }\end{array}$ & 1.30 & - & $2.880 .000,00$ \\
\hline & $\begin{array}{l}\text { Healthcare officer of } \\
\text { Yogyakarta }\end{array}$ & ND & - & ND \\
\hline & $\begin{array}{l}\text { Priest from clinic of } \\
\text { traditional medic }\end{array}$ & 1.7 & - & $30.000 .000,00$ \\
\hline \multirow{13}{*}{$\begin{array}{l}\text { Industry } \\
\text { Cluster }\end{array}$} & Entrepreneur of small & 1.16 & $1.680 .000,00$ & $106.680 .000,00$ \\
\hline & scale of herbal industry & & & \\
\hline & $\begin{array}{l}\text { Owner of modern of } \\
\text { herbal grocery store }\end{array}$ & 10.91 & ND & ND \\
\hline & $\begin{array}{l}\text { Officer of National } \\
\text { newspaper }\end{array}$ & 0.8 & $150.000 .000 .000,00$ & - \\
\hline & $\begin{array}{l}\text { Officer of Center of bio- } \\
\text { pharmacy studies of } \\
\text { Bogor Agricultural } \\
\text { University }\end{array}$ & 1.25 & ND & - \\
\hline & $\begin{array}{l}\text { Head of Indonesia herbal } \\
\text { cooperation }\end{array}$ & 1.67 & $6.050 .000,00$ & - \\
\hline & $\begin{array}{l}\text { Herbal entrepreneur } \\
\text { associ ation of Central } \\
\text { Java Province }\end{array}$ & 10 & $150.000,00$ & - \\
\hline & Apothecary I & 3.33 & & - \\
\hline & Apothecary II & 2 & - & $18.750 .000,00$ \\
\hline & $\begin{array}{l}\text { Board of drugs and foods } \\
\text { officer of Central Java } \\
\text { Province }\end{array}$ & 1 & & - \\
\hline & $\begin{array}{l}\text { Entrepreneur of middle } \\
\text { scale of herbal industry }\end{array}$ & 1.3 & $3.450 .000 .000,00$ & - \\
\hline & $\begin{array}{l}\text { Entrepreneur of big scale } \\
\text { of herbal industry }\end{array}$ & 3 & $2.000 .000 .000,00$ & - \\
\hline & $\begin{array}{l}\text { Commerce and industry } \\
\text { officer Sukoharjo District }\end{array}$ & 1 & - & $700.000 .000,00$ \\
\hline
\end{tabular}


goods. They just planned how long they would be in forest to harvest raw materials and how many place of accommodation they need. Usually, harvesters live for 2 weeks in forest. After that, they sell the products directly to buyers who lived in their village and earn income for family (Magid et al. 2014). Harvester activities finish at this step. There is a difference between farmers who plant medicinal plants in their land farm with the harvesters. Generally, for farmers and by this system plant specific species of medicinal plants i.e. ginger, curcuma and turmeric in their own land. Those species are only harvested in one day per year because those products become second income for farmers. Although they never go to forest, they have capacity to supply raw material of medicinal plants in huge numbers because they bound into group with 700 members producing same products. It is also created beneficiaries for farmers and by those system, they earn extra income from medicinal plant products.

Table 3 is relatively still lower, stakeholders also have interests on sustainability. They thought that sustainability is an important term in their works. Except healthcare cluster, production and industry clusters to consider sustainability as an important issue because most of their income depends on forest product availability. Yet in this study, sustainability value in Table 3 is relatively still lower than economic value. It means that forest as provider of raw material of medicinal plant is still not considered as important value since forest did not supply economic goods for users. Even though there is an expectation in future that management of medicinal plant could be regenerated because users in two clusters have considered sustainability in their thought (Bukuluki et al. 2014). This situation will encourage users to maintenance their interest on medicinal plant products in order to provide in nature. Therefore, users also maintain their income.

In healthcare cluster, stakeholders have the highest perception and motivation in social activities i.e. $63.15 \%$ and $68.4 \%$. It means that traditional healthcare by medicinal plants is important activity for them. Table 2 shows that stakeholders of traditional healthcare accept the highest benefit from those activities because traditional healthcare as an ancient tradition has lived for long time in Indonesian communities. Almost in every place, we would meet traditional healers who lived and serviced as "doctors" for their communities. People need them not only the healers have become "doctor" but also economic reason. Most of people often follow healers suggestion, especially poor people in the community. For them, traditional healer is a problem solver who helps them to get health services. It is very rationalistic for traditional community when modern healthcare is very expensive and very difficult to reach. In this term, a traditional healer has posed certain social structure in community. Although government has provided traditional healthcare in hospital (see healthcare law No. $36 / 2009$ article 48 ), but number of patients getting traditional healthcare services is still a little. It is quite different with traditional healthcare clinics which have a big numbers of patients. For example, a number of patients in modern hospitals are approximately 51-750 persons a year and in traditional clinic are at least 4.000-90.000 persons a year. The data was taken by interview to stakeholders in November 2014-August 2015, and those data indicate that traditional healthcare tends to social mainstream in this cluster. It also has closely correlation with user's perception and motivation in Table 1 that cheap, safety, healthcare service and church social services are keywords in respondent comments. It answer the question, why in healthcare cluster that social activity has become dominant value. In fact, traditional healthcare still becomes traditional thought in their social life (Vandebroek et al. 2004).

BCR and transaction cost In Table 2, the highest value in production cluster is farmers group but it has the lowest of transaction cost. It is reasonable because farmers have ability to manage their own land farm so that it provided them with ability to defend their rights to the land (Zhang 2000; Barron \& Karpoff 2002; Liu 2004). Sometimes, some farmers use the TNMB land area and spent low cost into those land area because managers of TNMB and NGO also need local people to participate in their projects. One of

Table 3 The use values of medicinal plants which correlate to stakeholder's perception and motivation

\begin{tabular}{|c|c|c|c|}
\hline Clusters & Use values & Perception (\%) & Motivation (\%) \\
\hline \multirow[t]{5}{*}{ Production } & Sustainability & 40 & 30 \\
\hline & Social & - & - \\
\hline & Economic & 50 & 60 \\
\hline & Heritage & - & - \\
\hline & Others & 10 & 10 \\
\hline \multirow[t]{5}{*}{ Healthcare } & Sustainability & - & - \\
\hline & Social & 63.15 & 68.42 \\
\hline & Economic & 15.79 & 10.52 \\
\hline & Heritage & 15.79 & 15.79 \\
\hline & Others & 5.26 & 5.26 \\
\hline \multirow[t]{5}{*}{ Industry } & Sustainability & 8.33 & - \\
\hline & Social & 8.33 & 16.67 \\
\hline & Economic & 83.33 & 75 \\
\hline & Heritage & - & 8.33 \\
\hline & Others & - & - \\
\hline
\end{tabular}


important project in MBNP is rehabilitation land project which was continued and managed by NGO for more than twenty years. They build collaboration among MBNP, NGO and farmers group to conserve forest land area by planting multipurpose tree species (MPTS) such as medicinal plants, crop plants and others. In those projects, they designed medicinal plants mixing with crop plants and usually those activities were continued in three years. It concludes that by those projects, farmers have opportunities on earning in short time financial benefit in three years. It is promptly necessary because the manager expected, by those benefit, farmers to be under their controlled in order not to encroach forest land. After twenty years, this project gave impact to their collaboration which MBNP, NGO and farmers group have a same perception and motivation to conserve natural forest. This collaboration was able to meet such interest among managers and farmers group on economic and medicinal plants sustainability.

Other activities, there are medicinal plant harvesters and loggers actively harvesting natural resources from MBNP. By national law, medicinal plant harvesting is formally not illegal activities. It has been ruled in law Number 5/1990 about biodiversity and ecosystem and also national law number 41/1999 about forestry. It means that state supports medicinal plant harvesting in nature because those activities considered as traditional domain which local community earns income. Medicinal plant harvesters usually have already a specific plan to harvest medicinal plants within a year. It shows on Table 4 how harvesters have a schedule to harvest medicinal plants based on local seasons.

By the schedule, harvesters have certainty to earn income from medicinal plants and those also became a natural insurance for their family (Schreckenberg et al, 2006; Sill et al 2011; Dzerefos et al. 2012). It is important which harvesters and medicinal plants have a dependent relationship. Generally harvesters only pick mature parts of medicinal plants as raw materials. Those habbits become local wisdom to guarantee their sustainable benefit. In Table 2 , it shows that harvesters have lowest transaction cost than other users. It means that harvesting medicinal plants from nature are actually more efficient than others. It is possible because harvesters do not spend much money to harvest medicinal plants in forest. They usually get the money from buyers. After harverters finish and sell raw materials of medicinal plant, buyers will cut part of harvester income as paying loan before they go to forest. Although the transaction cost is relatively not significant, it does not mean that sustainability of raw materials are not threatened in future. In view of low benefit value and low transaction cost, harvesters will pick more raw materials as consequence. These phenomena was found through the interview session with the harvester and indicated that some species of medicinal plants become scarce in MBNP recently. Furthermore, manager of MBNP and NGO should pay attention to the medicinal plant condition in MBNP.

In healthcare cluster and industry cluster, users who have highest benefit and transaction cost are patients of traditional healers and owners of modern herbal grocery store. Their score for benefit and transaction cost was continuously from 16.67 to 0 and from 10.91 to 0 . It can be concluded that patients and owners of grocery store have benefit from social and business activities. Moreover, it is also indicated by 0 score of transaction cost which patients and owners of grocery store never spent money to manage their needs on medicinal plants (Zhang 2000; Barron \& Karpoff 2002; Liu 2004). Based on interview result, those users have assisted by other stakeholder to get traditional healthcare services and to rent herbal grocery stores. It became a reason why their transaction cost was very limited and other stakeholders have built mutualism relations by those activities. Before using traditional healthcare, patients generally use modern healthcare to cure their illness, but they feel that this process moves slowly eventhough they spent much money especially when they must stay overnight at hospital. For patients, this condition burdens their financial condition very much. As an alternative, they try to use herbal traditional healthcare. Using herbal medicine, patients usually get a positive progress which their blood pressure tends to be normal. Thus, it helps them to reduce the risk of heart attack and even stroke. Recently, it is good news for patients that herbal medicine also usefull in healthcare services and relatively cheaper compared to modern healthcare.

The other relation is owners of modern herbal grocery stores. For them, herbal medicine is still a great opportunity to earn income after pension from their formal work. They use knowledge of herbal to create some beverages for young foreign communities in the market class. They usually earn income from those activities. Moreover, national newspapers capture their activities as a positive aspect. It becomes a benefit for them because they got a cooperation project with Japanese to develop their products remove furtherly. They also admitted that their products are expensive although they bought cheap raw materials from suppliers. For those 2 cases, it is argued that these conditions are similar, which herbals are benefit products to cure illness and to earn income. On the other hand, there are some considerations that herbals should have a level of safety standard on their products in healthcare and industry clusters. It is quite important because in other place in Jawa Island, there was a death case which was experienced by herbal consumers. At that case, producers mixed herbals with raw material of chemical medicine to get maximum cured impact for consumers. Although government has introduced policies to prevent such case from happening, but ironically it still happened in the herbal business. For businessmen, herbal is interesting business to earn huge income. Similar case has happened in Cilacap District, Jawa Island and the same actors were caught twice in pangea operation. In fact, the case never stops and still continue nowadays. By this case, herbal image has been at lower condition compared to chemical medicine. It also has disturbed traditional healthcare services in hospitals because there was distrust among patients and healers to cure their illness using traditional techniques by herbals. As a consequences, the herbal image has been tarnished compared to number of patients in modern hospitals is bigger than traditional clinic. These incidents also affect the traditional healthcare services. Therefore, there is a trend in higher number of patients in modern hospitals compare to traditional clinic. Trust relationship between healers and patients is absolutely more important to get optimum healthcare services (Vandebroek et.al. 2004). 
In Table 2, the lowest benefit has been owned by national newspapers. Based on interview to the officers, national newspapers actually subsidize a newspaper reader approximately IDR 2,000 per exemplar a day, with a number of production almost five hundred thousand newspapers a day. Although this newspaper is not their main business yet, but it was still printing every day because the newspaper gives people more information about government policy, society activities, economics, opinions, and others, includes herbals. This business has developed into a huge business such as bookstores, hotels, printings, advertising and highway toll, and by those, the loss of newspaper business could be subsidized. Table1 shows that the newspaper has a vision to report and develop small scale industries by their reporting. It is important for business because it provides employments, withstands shock economy and labor intensive. Furthermore, the newspaper hopes it will influence decision makers on developing medicinal policies (Kitzberger 2012). One example is that the Ministry of Agriculture has been involved along with Ministry of Health and other relevant stakeholders in discussion about herbal development which is never reported in newspaper. It helps the stakeholders to conduct comprehensive policy about herbal and medicinal plant management. By the time, various herbal policies have been arranged by stakeholders to get approval from parliament as national law of herbal management in Indonesia.

Related to the transaction, there are lump sum and ad valorem cost in production, industry and traditional healthcare clusters which also flow in legal or illegal transactions. In Table 5, transaction on raw materials of medicinal plant occurred in ad valorem and lump sum and at legal condition. It also describes that transactions cost in traditional healthcare and industrial clusters are legal transaction where raw materials of medicinal plant in those clusters are more institutional than in production cluster. Tax payment, commission and other payment have been regularly accounted by certain actors so that they have high certainty in this business. Yet, different situation occurred in production cluster. Illegal transaction cost still occurs where some actors harvested raw material of medicinal plant i.e. Pterospermum javanicum and Tectona grandis. $P$. javanicum produces sap besides wood. Moreover, leafs of $T$. grandis are also used for serving foods at remote area close to forest. Illegal transaction occurred in those species which actors used them as log timber because those logs have expensive price in logs market. Stealing from MBNP forest and it become a concern for the forest governance in MBNP. In conducting illegal activities, the actors already have

Table4. Medicinal plants harvester's schedule in a year

\begin{tabular}{ll}
\hline Species & \multicolumn{1}{c}{ Seasons } \\
\hline Terminalia bellerica Roxb & February-March \\
Aleurites moluccana (L.)Willd. & March-May, September November \\
Pangium edule Reinw & March-May \\
Piper cubeba L. & June-July \\
Honey bee & June-July \\
Parkia roxburghi G.Don & September-October \\
\hline
\end{tabular}

networks of truck drivers, unethical police officers and forest rangers so that it is quite difficult to catch all of them by MBNP authority. This network is also helped them to get good information about law enforcement activities and to avoid legal authority. As a consequences, those actors must pay illegal transaction costs for the such informantion. This transaction also means protection cost for actors. Based on benefit and transaction cost described, there are asymmetric information where stakeholders in production cluster still faced illegal activities than other clusters (Schafsma et al. 2014). Commercialization of medicinal plant raw materials, in reality, is occurring in industrial and traditional healthcare clusters where stakeholders in those clusters are able to create demand of raw materials which are needed by their consumers. This commercialization also needs supports from stakeholders who lived and actively harvested raw materials of medicinal plant in production cluster so that replace of hose to those raw materials utilization will be reached by all stakeholders.

In production cluster, there were no open conflicts among stakeholders to utilize medicinal plants, although competition among them was also happened. Potentially conflicts were only occurred at stakeholder level who utilizes dual function of medicinal plants as explained before. Furthermore, stakeholders looked this situation as an institutional weakness of MBNP management to uphold rules which affected stakeholder's view to work on the right track. In Table 1, it is also seen that there were different motivation and perception among stakeholders which commerce interest was more important than sustainability. As consequence, this weakness will increase the transaction costs i.e. monitoring cost and maintenance cost which its existence addressing inefficiency of forest governance in MBNP (Kartodihardjo 2008). On the other hand, the existence of transaction costs also are needed by stakeholders to arrange the institution because there is no free charged for involving other stakeholders to participate in common interests (Mbuvi et al. 2015; Maryudi et al. 2011; Zhang 2000). One of good example which is parallel to that condition is developing share holder system in forest governance in China. Farmers and community forests are involved in common interests to manage their forest and to give impact for increasing certainty of forest governance (Zhang 2000).

Table5 Lump sum and Ad valorem Transaction Cost in Clusters

\begin{tabular}{lcc}
\hline Item & Lump sum & Ad valorem \\
\hline Production cluster & \multicolumn{2}{c}{-} \\
Legal transaction & $6(60 \%)$ & - \\
Illegal transaction & $3(30 \%)$ & $11(57.89 \%)$ \\
\hline Traditional Healthcare cluster & & - \\
\hline Legal transaction & $5(26.31 \%)$ & $5(41.66 \%)$ \\
Illegal transaction & - & - \\
\hline Industry cluster & \multicolumn{2}{c}{} \\
\hline Legal transaction & $3(25 \%)$ \\
Illegal transaction & - & - \\
\hline
\end{tabular}




\section{Conclusion}

It is concluded that commercialization of MPRM has involved many stakeholders who each stakeholder has different perception and motivation to utilize the raw materials. The stakeholder's perception and motivation in production and industrial clusters focused on economic interest and in traditional cluster is controlled by social interest. From 41 stakeholders involved in that clusters, stakeholders in traditional healthcare and stakeholders in industrial cluster have been able to manage their interests in commercing raw materials of medicinal plant better than production cluster. This situation made both clusters were more efficient rather than production cluster. There are two models of transaction cost in those clusters i.e. lump sum and ad valorem. The lump sum and ad valorem transactions in both traditional healthcare and industrial clusters have legal transactions compared to production cluster; hence these clusters are more manageable. Their transactions were also more efficient than those of in production cluster because there were no illegal activity where stakeholders must pay more to defend their property. In this situation, stakeholders in all clusters need institutionally arrangement to fix commercial system of raw materials of medicinal plant from MBNP in order to reach sustainability of medicinal plant utilization (Nurrochmat et.al. 2014).

\section{References}

Baron OE, Karpoff JM. 2004. Information precision, transaction costs, and trading volume. Journal of Banking \& Finance 28:1207-1223. http://dx.doi.org/10.1016/ S0378-4266(03)00115-8.

Bauri T, Palit D, Mukherjee A. 2015. Livelihod dependency of rural people utilizing non-Timber forest product (NTFP) in a moist deciduous forest zone, West Bengal, India. International Journal of Advanced Research 3(4):1030-1040.

Beers SJ. 2013. Jamu Sakti: Basmi Penyakit, Awet Muda dan Kecantikan. Jakarta: PT Ufuk Publishing House.

Bhattacharjee S. 2012. Multidicplinary research can make the medicinal plant industry In Tripura Viable-A concept study based on tows matrix. International Journal of Multidiciplinary Research 2(5):146-154.

Brinckmann JA. 2014. Geographical indications for medicinal plants: globalization, climate change, quality and market implications for geo-authentic botanicals. Modern Research on Chinese Materia Medica 1(1):16-23.

Bryant RL, Bailey S. 1997. Third World Political Ecology. Routledge. London and New York.

Bukuluki P, Luwangula R, Walakira EJ. 2014. Haresting of medicinal plants in uganda: practices, conservation and implication for sustainability of supplies. Online International Journal of Medicinal Plants Research 3(1):1-10.

Collins BM, Fabozzi FJ. 1991. A methodology for measuring transaction costs. Financial Analysts Journal 47:27-36. http://dx.doi.org/10.2469/faj.v47.n2.27.

Crozet M, Soubeyran PK. 2004. EU enlargement and the internal geography of countries. Journal of Comparative Economics 32:265-279. http://dx.doi.org/10.1016/j.jce. 2004.02.009.

Dewoto HR. 2007. Pengembangan obat tradisional indonesia menjadi fitofarmaka. Majalah Kedokteran Indonesia 57(7):205-211.

Dzerefos CM, Witkowski ETF, Toms R. 2014. Use of the Stinkbug, Encosternum delegorguei (Hemiptera Tessaratomidae), for Fod and Income in South Africa. London: Routledge.

[FAO] Food Agriculture Organization. 1995. Non Wood Forest Product for Rural Income and Sustainable Forestry. Rome: FAO.

Fibriani D. 2012. Evaluasi proses implementasi kebijakan hutan rakyat di Kabupaten Sarolangun, Jambi [disertation]. Bogor: Sekolah Pasca Sarjana IPB.

Guay F, Chanal J, Ratelle CF, Marsh HW, Larose S, Boivin M. 2010. Intrinsic, identified, and controlled types of motivation for school subject in young elementary school children. British Journal of Educational Psychology 80:711-735. http://dx.doi.org/10.1348/000709910X4 99084.

Hamilton AC. 2004. Medicinal plants, conservation and livelihoods. Biodiversity and Conservation 13:1477-1517. http://dx.doi.org/10.1023/B:BIOC. 0000021333.23413 .42

Hermans LM, Thiessen WAH. 2008. Actor analysis methods and their use for public policy analysis. European Journal of Operation Research 196:808-818. http://dx.doi.org/ 10.1016/j.ejor.2008.03.040.

Hornock L. 1992. Cultivation and Processing of Medicinal Plants. United Kingdom: John Wiley and Sons.

Jayakumar K. 2014. Ethno medicinal value of plants in Thanjavur district, Tamil Nadu, India. International Letters of Natural Sciences 29:33-42. http://dx.doi.org/ 10.18052/www.scipress.com/ILNS.29.33.

Kartodihardjo H. 2008. Dibalik Kerusakan Hutan dan Bencana Alam: Masalah Transformasi Kebijakan Kehutanan. Serpong: Wana Aksara.

Kitzberger P. 2012. The media politics of Latin America's leftist governments. Journal of Politics in Latin America 4:123-139.

Kockelman P. 2006. A semiotic ontology of the commodity. Journal of Linguistic Anthropology 16(1):76-102. http://dx.doi.org/10.1525/jlin.2006.16.1.076.

Kunwar SC, Ansari AS, Luintel H. 2009. Non timber forest 
products enterprise development: regulatory challenges in Koshi Hills of Nepal. Journal of Forest and Livelihood 8(2):39-50. http://dx.doi.org/10.3126/jfl.v8i2.2307.

Lai ER. 2011. Motivation: A Literature Review. http://www.pearsonassessments.com/.

Liu H. 2004. Optimal consuption and investment with transaction costs and multiple risky assets. The Journal of Finance 59:289-338. http://dx.doi.org/10.1111/j.15406261.2004.00634.x.

Magid TDA, El Tiab A, Abdalla, El Nour A., El Siddiq. 2014. Participatory management of natural forest in Sudan-case of El Rawashda forest reserve, Gedaref State. Journal of Forest Products \& Industries 3(3):124-129.

Mamat, MF, Yacob MR, Lim HF, Rdam A. 2010. Costs and benefits analysis of Aquilaria Species on plantation for agarwood production in Malaysia. International Journal of Business and Social Science 1:162-174.

Marsh D, Stoker G. 2011. Teori dan Metode dalam Ilmu Politik. Bandung: Nusa Media. Maryudi A, Devkota RR, Schusser C, Yufanyi C, Salla M, Aurenhammer H, Rotchanaphatarawit R, Krott M. 2011. Back to Basic: Considerations in Evaluating the Outcomes of Community Forestry. Forest Policy and Economics 30:1 - 5.

Maryudi A, Devkota RR, Schusser C, Yufanyi C, Salla M, Aurenhammer H, Rotchanaphatharawit R, Krott M. 2011. Back to basic: Consideration in evaluating the outcomes of community forestry. Forest Policy and Economics 30:1-5

Mbuvi MTE, Musyoki JK, Ayiemba WO, Gichuki JW. 2015. Determining the potential for introducing and sustaining participatory forest management: a case study of south nandi forest of Western Kenya. International Journal of Biodiversity and Conservation 7(3):190-201. http://dx. doi.org/10.5897/IJBC2014.0786.

Mehrabi J, Soltani I, Nilipour A, Kiarasi P. 2013. Studying Knowledge Commercialization. International Journal of Academic Research in Business and Social Sciences 3(7):267-278. http://dx.doi.org/10.6007/IJARBSS/v3i7/44.

Nurrochmat DR, Yovi EY, Hadiyati O, Sidiq M, Erbaugh JT. 2015. Changing policies over timber supply and its potential impacts to the furniture industrial of Jepara, Indonesia. Jurnal Manajemen Hutan Tropika 21(1):36-44. http://dx.doi.org/10.7226/jtfm.21.1.36.

Reed MS, Grave A, Dandy N, Posthumus H, Hubacek K, Morris J, Prell C, Quinn CH, Stringer LC. 2009. Who's in and why? A typology of stakeholder analysis methods for natural resources management. Journal of Environmental Management 90: 1933-1949. http://dx.doi.org/10.1016 j.jenvman.2009.01.001.

Schafsma M, Burgess ND, Swetnam RD, Nganga YM, Turner RK, Treue T. 2014. Market signals of unsustainable and inequitable forest extraction: assessing the value of illegal timber Trade in the Eastern Arc Mountain of Tanzania. World Development 62:155-168. http://dx.doi.org/10.10 16/j.worlddev.2014.05.011.

Shapiro SP. 2005. Agency theory. Annual Review of Sociology 31:263- 284.Singh R. 2015. Medicinal plants: A review. Journal of Plants Sciences 3:50-55. http://dx.doi.org/10. 1146/annurev.soc.31.041304.122159.

Stenley D, Voeks R, Short Leaa. 2012. Is non-timber forest product harvest sustainable in the less developed world? a systematic review of the recent economic and ecological literature. Ethnobiology and Conservation 1:1-39. http://dx.doi.org/10.15451/ec2012-8-1.9-1-39.

Taylor A. 2002. The impact of commodification of herbal medicine by pharmaceutical and drug development companies. Nexus 13:55-68.

Tita DF, D'Haese M, Degrande E, Tchoundjeu Z, Van Damme P. 2011. farmer's satisfaction with group market arrangements as a measure of group market performance: a transaction cost analysis of non timber forest product's producers groups in Cameroon. Forest Policy and Economics 13:545-553. http://dx.doi.org/10.1016/ j.forpol.2011.07.005.

Torri MC. 2012. The jamu system in indonesia: linking small scale enterprises, traditional knowledge and social empowerment among Women in Indonesia. Journal of International Women's Studies 13(1):31-45.

Vandebroek I, van Damme P, van Puyvelde L, Arrazola S, de Kimpe N. 2004. A comparison of traditional healer's medicinal plant knowledge in the Bolivian Andes and Amazon. Social Science and Medicine 59:837-849. http://dx.doi.org/10.1016/j.socscimed.2003.11.030.

Wang Y. 2007. On the cognitive processes of human perception with emotions, motivation, and attitudes. International Journal of Cognitive and Natural Intelegence 1(4):1-13. http://dx.doi.org/10.4018/jcini. 2007100101.

Wang Z. 2010. Regulating debit cards: the case of ad valorem fees. Federal reserve bank of Kansas City, pp 71-99.

Yustika AE. 2006. Ekonomi kelembagaan; definisi, teori dan strategi. Malang: Bayumedia.

Zhang Y. 2000. Commentary economics of transaction costs saving forestry. Ecological Economics 36:197-204. http://dx.doi.org/10.1016/S0921-8009(00)00228-7.

Zuhud EAM, Hikmat A. 2009. Hutan Tropika Indonesia Sebagai Gudang Obat Bahan Alam Bagi Kesehatan Mandiri Bangsa. In: Tinambunan D, Wibowo A, Editors. Bunga Rampai Biofarmaka Kehutanan Indonesia: Dari Tumbuhan Hutan untuk Keunggulan Bangsa dan Negara. Bogor. Indonesia . Bogor: Pusat Litbang Hutan Tanaman. Badan Litbang Kehutanan. 